KRUBNIKI, João Pedro Ruppert. A supremacia do interesse público como princípio do Direito Ambiental. Revista Eletrônica Direito e Política, Programa de Pós-Graduação Stricto Sensu em Ciência Jurídica da UNIVALI, Itajaí, v.13, n.2, $2^{\circ}$ quadrimestre de 2018. Disponível em: www.univali.br/direitoepolitica - ISSN 1980-7791

\title{
A SUPREMACIA DO INTERESSE PÚBLICO COMO PRINCÍPIO DO DIREITO AMBIENTAL
}

\author{
THE SUPREMACY OF PUBLIC INTEREST AS A PRINCIPLE OF THE \\ ENVIRONMENTAL LAW
}

\section{João Pedro Ruppert Krubniki ${ }^{1}$}

SUMÁRIO: Introdução; 1 A relativa autonomia do Direito Ambiental; 2 A Administração Pública na defesa do meio ambiente; 30 suposto caráter autoritário do Direito Administrativo e os ataques à noção de interesse público; $4 \mathrm{~A}$ relação entre os interesses públicos e difusos e a supremacia do interesse público como princípio do Direito Ambiental; Considerações Finais; Referência das fontes citadas.

\section{RESUMO}

O presente artigo busca analisar a caracterização, ou não, do princípio da supremacia do interesse público como um princípio aplicável ao Direito Ambiental. De um lado, ao se notar que a legislação ambiental se declara autônoma relativamente ao Direito Administrativo, pode se cogitar de um abandono ou mitigação do regime jurídico administrativo, pautando-se na especificidade do tratamento legal conferido aos direitos difusos e na vinculação dos direitos fundamentais ao princípio da proporcionalidade. Por outro lado, pode se reafirmar a coexistência, no plano normativo, do princípio da supremacia do interesse público e da proporcionalidade, de modo que o fundamento constitucional do princípio da supremacia do interesse público sobre o privado imporia que ele fosse aplicado também ao Direito Ambiental. Como metodologia, procedeu-se a uma análise descritiva do objeto em estudo, através de pesquisa baseada em documentação indireta documental e bibliográfica.

Palavras-chave: Proporcionalidade; meio ambiente; direito administrativo; autonomia.

\section{ABSTRACT}

The present manuscript aims to analyze the characterization, or not, of the principle of the supremacy of public interest as an applicable principle of the Environmental Law. On one hand, by noticing the fact that the environmental legislation declares itself autonomous relatively to the Administrative Law, it is

1 Mestrando em Direito do Estado pela Universidade Federal do Paraná (UFPR). Bolsista da CAPES/PROEX. Membro do Núcleo de Pesquisa em Direito Administrativo, Urbanístico, Ambiental e Desenvolvimento, vinculado ao Programa de Pós-Graduação em Direito da Universidade Federal do Paraná (PRO POLIS/PPGD-UFPR). Bacharel em Direito pela Universidade Estadual de Ponta Grossa (UEPG). E-mail: jprkrubniki@gmail.com. 
KRUBNIKI, João Pedro Ruppert. A supremacia do interesse público como princípio do Direito Ambiental. Revista Eletrônica Direito e Política, Programa de Pós-Graduação Stricto Sensu em Ciência Jurídica da UNIVALI, Itajaí, v.13, n.2, $2^{\circ}$ quadrimestre de 2018. Disponível em: www.univali.br/direitoepolitica - ISSN 1980-7791

possible to consider an abandonment or mitigation of the administrative juridical regimen, based on the specific legal treatment required by the diffuse rights and the binding of fundamental rights to the principle of proportionality. One the other hand, it can be asserted that the principles of the supremacy of public interest and proportionality coexist normatively, so that the constitutional basis of the principles of the supremacy of public interest requires it to also be applicable to the Environmental Law. Methodologically, a descriptive analysis of the studied object was carried out, trough a research based on indirect documental and bibliographic documentation.

Keywords: Proportionality; environment; administrative law; autonomy.

\section{INTRODUÇÃO}

Em âmbito doutrinário, tem se sustentado que o Direito Ambiental surge na Década de 1960, encontrando-se ligado aos movimentos sociais desde a sua origem, nos quais encontra suas raízes, conservando premissas éticas atribuídas pela comunidade. A vinculação a movimentos sociais reivindicativos de uma nova ética teria conferido ao Direito Ambiental uma especialização relativamente aos demais ramos do direito, fornecendo-Ihe leis e princípios próprios.

Porém, não se deve ignorar que a formação de legislações que tratam da relação entre o homem e o meio ambiente não passa a ocorrer somente após as reivindicações dos movimentos ambientalistas. Mesmo antes do reconhecimento da especialização do Direito Ambiental, a regulação legal do meio ambiente já se encontrava positivada.

Exemplos como os Códigos Florestal, de Águas, de Pesca, e as Leis de Proteção aos Animais e do Patrimônio Histórico e Artístico Nacional, todos da década de 1930, demonstram que a regulação da matéria antecede o reconhecimento da autonomia do Direito Ambiental. Até então, a matéria era considerada como pertencente ao ramo do Direito Administrativo.

Essa constatação adquire relevância quando se considera que, não obstante grande parte da legislação ambiental tenha origem no Direito Administrativo, sendo norteada pelo regime jurídico administrativo e implementada através do exercício da função administrativa, por vezes a doutrina jusambientalista, pautada na confusão conceitual entre direitos difusos e direito público, e nos discursos de 
KRUBNIKI, João Pedro Ruppert. A supremacia do interesse público como princípio do Direito Ambiental. Revista Eletrônica Direito e Política, Programa de Pós-Graduação Stricto Sensu em Ciência Jurídica da UNIVALI, Itajaí, v.13, n.2, $2^{\circ}$ quadrimestre de 2018. Disponível em: www.univali.br/direitoepolitica - ISSN 1980-7791

vinculação dos direitos fundamentais ao princípio da proporcionalidade, defende que eventual primazia do meio ambiente não decorre do princípio da supremacia do interesse público, mas sim da ponderação de interesses, requerendo, em todo caso, uma atividade interpretativa.

Desse modo, busca se demonstrar que o princípio da supremacia do interesse público não somente é atacado por parcela da doutrina administrativista (que o considera conceitualmente indeterminado, autoritário e ultrapassado), como também parcela da doutrina jusambientalista tem sustentado que este princípio não diz respeito à proteção do meio ambiente, sendo que este, por ser um interesse difuso, e não público, prevaleceria apenas nos casos em que o princípio da proporcionalidade assim estabelecesse.

Para a elaboração do artigo, procedeu-se a uma análise descritiva do objeto em estudo, através de pesquisa baseada em documentação indireta documental e bibliográfica. Ademais, objetivou-se demonstrar a íntima relação entre o Direito Administrativo e o Direito Ambiental, traçar um panorama do debate acerca do princípio da supremacia do interesse público sobre o privado e esclarecer as (in)distinções conceituais relativas aos interesses públicos e difusos, para então se argumentar a favor ou contra a caracterização da supremacia do interesse público como um princípio do Direito Ambiental.

\section{A RELATIVA AUTONOMIA DO DIREITO AMBIENTAL}

Apesar de desde o início das civilizações terem existido problemas ambientais em maior ou menor grau, a preocupação com a preservação da natureza só ganhou contornos jurídicos muito recentemente. É com a inserção da pauta ambiental no debate institucional que um novo espaço político passou a ser reivindicado e ocupado pela sociedade civil organizada.

É especialmente a partir da Década de 1960 que o movimento ambientalista começa a ganhar repercussão. A natureza deixava de ter caráter meramente instrumental e estético, reconhecendo-se a existência uma ética ambiental. Os interesses em defesa do meio ambiente levaram à criação de entidades protetoras do meio ambiente, como a WWF (World Wide Fund for Nature), Greenpeace, 
KRUBNIKI, João Pedro Ruppert. A supremacia do interesse público como princípio do Direito Ambiental. Revista Eletrônica Direito e Política, Programa de Pós-Graduação Stricto Sensu em Ciência Jurídica da UNIVALI, Itajaí, v.13, n.2, $2^{\circ}$ quadrimestre de 2018. Disponível em: www.univali.br/direitoepolitica - ISSN 1980-7791

Friends of Earth, IUCN (International Union for Conservation of Nature), entre outras. $^{2}$

A partir da Década de 1980, partidos políticos vêm a ser criados com a proteção do meio ambiente em sua pauta. Começam a ser formuladas as primeiras legislações que reconhecem um valor intrínseco ao ambiente, especialmente nos pioneiros Estados Unidos e Alemanha.

No entrecho do governo ditatorial militar, o movimento ambientalista brasileiro surgiu apenas no início da Década de 1970, alinhando-se ideologicamente aos movimentos norte-americano e europeu. ${ }^{3}$ Dentre os casos que pautaram o movimento à época, pode-se citar a poluição excessiva no município de CubatãoSP, a construção das usinas nucleares Angra I e II, em Angra dos Reis-RJ, a construção da Usina Hidrelétrica de Itaipu, no Paraná, e o movimento em defesa da Floresta Amazônica, no qual era ativista Chico Mendes, no Acre ${ }^{4}$.

2 O histórico do movimento ambientalista é longo, não cabendo explicação detalhada neste trabalho. Em suma, até a década de 1960, prevalecia um modelo "conservacionista" de proteção ambiental: se preocupava com as utilidades que o ser humano poderia extrair do ambiente, e este era conservado essencialmente devido a seus proveitos econômicos e a valoração estética da natureza. A partir da década de 1960, se intensificando nos anos seguintes, impulsionado por diversos eventos que ocorriam na geopolítica da época, surge um movimento ambientalista que veio a defender um valor intrínseco ao meio ambiente, movimento este que perdura até hoje, influenciando entidades, partidos políticos e legislações. Deve-se destacar, ainda, que não se trata de um movimento isolado. A partir da década de 1960, diversas lutas sociais, como os movimentos pacifista, feminista, estudantil e por direito civis, faziam-se cada vez mais presentes no cenário político.

3 O movimento ambientalista brasileiro teve como instituição pioneira a AGAPAN - Associação Gaúcha de Proteção ao Ambiente Natural, fundada por José Lutzenberger e outros ecologistas, em 1971. Ainda havia resistência do governo militar às reivindicações ambientalistas, fato demonstrado pelas posturas contrárias à proteção ambiental expostas pelo representante do governo na Conferência de Estocolmo sobre o Meio Ambiente Humano, em 1972. Somente a partir da Década de 1980 é que a matéria começou a se desenvolver com maior sistemática, notadamente pela edição da Lei 6.938/81. A tendência Estadocêntrica pautada pelo discurso de desenvolvimentismo nos governos latino-americanos, tal como ocorreu no período ditatorial, repercute até hoje, colocandose em prática um modelo de política econômica predatório ao meio ambiente. Nesse sentido se posicionam autores como: SARLET, Ingo Wolfgang; FENSTERSEIFER, Tiago. Direito ambiental: introdução, fundamentos e teoria geral. São Paulo: Saraiva, 2014; e COCCO, Giuseppe. MundoBraz: O devir-mundo do Brasil e o devir-brasil do mundo. Rio de Janeiro: Record, 2009.

4 SARLET, Ingo Wolfgang; FENSTERSEIFER, Tiago. Direito ambiental: introdução, fundamentos e teoria geral. São Paulo: Saraiva, 2014, p. 90. 
KRUBNIKI, João Pedro Ruppert. A supremacia do interesse público como princípio do Direito Ambiental. Revista Eletrônica Direito e Política, Programa de Pós-Graduação Stricto Sensu em Ciência Jurídica da UNIVALI, Itajaí, v.13, n.2, $2^{\circ}$ quadrimestre de 2018. Disponível em: www.univali.br/direitoepolitica - ISSN 1980-7791

Em resumo, na investigação das motivações do movimento ambientalista, são apontados a iminência dos riscos da modernidade, o déficit de integração social e a emergência de preocupações com uma ética ambiental. Para tanto, busca-se uma normatividade que atenda a esses novos pressupostos, usufruindo do caráter reflexivo dos novos tempos ${ }^{5}$. Nesse contexto, surge o Direito Ambiental, cuja razão de ser reside justamente na legitimação político-comunitária que lhe antecede, de maneira que "há uma relação direta de causalidade entre a ocorrência da poluição e degradação ecológica, a mobilização social em prol da Natureza e a regulação normativa da matéria"6.

Em outras palavras, esse novo ramo do direito está ligado aos movimentos sociais desde a sua origem, nos quais encontra suas raízes, bem como a certos fins, sempre conservando as premissas éticas atribuídas pela comunidade.

É possível encontrar diversos conceitos de Direito Ambiental. Sem adentrar nas especificidades conceituais, deve se destacar que, em suma, trata-se do ramo do direito responsável pela regulação legal da interação do homem com o meio ambiente. Para Paulo de Bessa Antunes ${ }^{7}$, o Direito Ambiental, para além de organizar a forma pela qual a sociedade utiliza os recursos ambientais, também estabelece os meios em que a apropriação econômica deve ocorrer. Para o autor, que adota uma perspectiva nitidamente antropocêntrica, na regulação econômica dos bens ambientais reside a própria finalidade do direito ambiental.

Entretanto, a formação de legislações que tratam da relação entre o homem e o meio ambiente não passa a ocorrer somente após as reivindicações dos movimentos ambientalistas. Esses movimentos conferiram coesão e uma proposta ética e principiológica diferenciada para a regulação do meio ambiente, o que

5 TAVOLARO, Sérgio Barreira de Faria. Movimento ambientalista e modernidade: Sociabilidade, risco e moral. São Paulo: Annablume/Fapesp, 2001. p. 42-43.

${ }^{6}$ SARLET, Ingo Wolfgang; FENSTERSEIFER, Tiago. Direito ambiental: introdução, fundamentos e teoria geral. São Paulo: Saraiva, 2014, p. 147.

${ }^{7}$ ANTUNES, Paulo de Bessa. Direito Ambiental. 12. ed. Rio de Janeiro: Lumen Juris, 2009, p. 11. 
KRUBNIKI, João Pedro Ruppert. A supremacia do interesse público como princípio do Direito Ambiental. Revista Eletrônica Direito e Política, Programa de Pós-Graduação Stricto Sensu em Ciência Jurídica da UNIVALI, Itajaí, v.13, n.2, $2^{\circ}$ quadrimestre de 2018. Disponível em: www.univali.br/direitoepolitica - ISSN 1980-7791

culminou no reconhecimento de sua relativa autonomia, mas mesmo antes deles a regulação legal do meio ambiente já se encontrava positivada.

Exemplos como os Códigos Florestal, de Águas, de Pesca, e as Leis de Proteção aos Animais e do Patrimônio Histórico e Artístico Nacional, todos da década de 1930, demonstram que a regulação da matéria antecede o reconhecimento da autonomia do Direito Ambiental. Até então, a matéria era considerada como pertencente ao ramo do Direito Administrativo.

Quer se reconheça a autonomia adquirida pelo Direito Ambiental como meramente didática, como didático-científica, ou se prefira utilizar o termo "especialização", em vez de "autonomia", fato é que a regulação jurídica do meio ambiente mantém sua unicidade normativa relativamente às demais disciplinas jurídicas, ou seja, não obstante se possa cogitar de princípios específicos nos diversos ramos do direito, estes compõem o mesmo ordenamento jurídico, estando igualmente sujeitos a influxos gerais a respeito da formação e aplicação do direito.

Nesse sentido, sustenta-se que o Direito Ambiental se mostra como disciplina especializada, mas não independente, de modo que the cabe congregar conhecimentos de uma série de outras disciplinas e ciências, jurídicas ou não ${ }^{8}$. Nesse sentido, o Direito Ambiental

[...] não se encontra "paralelo" a outros "ramos" do Direito. O DA é um direito de coordenação entre estes diversos "ramos", e, nesta condição, é um Direito que impõe aos demais setores do universo jurídico o respeito às normas que o formam, pois o seu fundamento de validade é emanado diretamente da Norma Constitucional. ${ }^{9}$

Essa constatação adquire relevância quando se trata de analisar os limites ou a extensão da autonomia dos diversos ramos do direito. Como se demonstrará, não obstante grande parte da legislação ambiental tenha origem no Direito Administrativo, sendo norteada pelo regime jurídico administrativo e

8 MILARÉ, Édis. Direito do Ambiente: A gestão ambiental em foco: doutrina, jurisprudência, glossário.6. ed. Ver, atual e ampl. RT, São Paulo, 2009, p. 837.

${ }^{9}$ ANTUNES, Paulo de Bessa. Direito Ambiental. 12. ed. Rio de Janeiro: Lumen Juris, 2009, p. 23. 
KRUBNIKI, João Pedro Ruppert. A supremacia do interesse público como princípio do Direito Ambiental. Revista Eletrônica Direito e Política, Programa de Pós-Graduação Stricto Sensu em Ciência Jurídica da UNIVALI, Itajaí, v.13, n.2, $2^{\circ}$ quadrimestre de 2018. Disponível em: www.univali.br/direitoepolitica - ISSN 1980-7791

implementada através do exercício da função administrativa, por vezes a doutrina jusambientalista, pautada na confusão conceitual entre direitos difusos e direito público e nos discursos de vinculação dos direitos fundamentais ao princípio da proporcionalidade, defende que eventual primazia do meio ambiente não decorre do princípio da supremacia do interesse público, mas sim da ponderação de interesses, requerendo, em todo caso, uma atividade interpretativa.

Caso se aceite que a legislação ambiental seja norteada pelo regime jurídico administrativo, é de se aceitar também, via de regra, que essa legislação esteja sujeita ao regime de prerrogativas e sujeições da Administração Pública, o qual inclui a supremacia do interesse público. Entretanto, buscará se demonstrar que essa posição não é aceita de maneira unânime, seja no âmbito da doutrina administrativista, seja no âmbito da doutrina ambientalista.

\section{A ADMINISTRAÇÃo PÚBLICA NA DEFESA DO MEIO AMBIENTE}

O principal dispositivo vigente no ordenamento jurídico pátrio que trata da proteção do meio ambiente é o artigo 225 da Constituição da República, que assim dispõe: "Todos têm direito ao meio ambiente ecologicamente equilibrado, bem de uso comum do povo e essencial à sadia qualidade de vida, impondo-se ao Poder Público e à coletividade o dever de defendê-lo e preservá-lo para as presentes e futuras gerações".

Com fundamento nesse artigo, o ordenamento jurídico brasileiro conta com ampla estrutura jurídica para concretizar a proteção ambiental. Embora as disposições normativas relativas à proteção ambiental tangenciem distintas áreas, notadamente o direito penal e civil, é essencialmente com o Direito Administrativo que essas normas se relacionam, concretizando-se através da atuação da Administração Pública.

Com efeito, os instrumentos jurídicos de proteção ao meio ambiente possuem, predominantemente, origem no Direito Administrativo, sendo norteados pelo regime jurídico administrativo e implementados no âmbito da função administrativa do Estado. As diversas expressões da Administração Pública se manifestam na concretização do dever de proteção ambiental. 
KRUBNIKI, João Pedro Ruppert. A supremacia do interesse público como princípio do Direito Ambiental. Revista Eletrônica Direito e Política, Programa de Pós-Graduação Stricto Sensu em Ciência Jurídica da UNIVALI, Itajaí, v.13, n.2, $2^{\circ}$ quadrimestre de 2018. Disponível em: www.univali.br/direitoepolitica - ISSN 1980-7791

Atos administrativos, poder de polícia, licenciamento, fiscalização - todos conceitos-chave do Direito Administrativo - são também conceitos-chave do Direito Ambiental, que se concretiza através dos mesmos. Exemplos como as licenças ambientais, a fiscalização de órgãos administrativos ambientais e a imposição de sanções administrativas pelo descumprimento da legislação ambiental, dentre outros, demonstram como o regime jurídico administrativo instrumentaliza a aplicação do Direito Ambiental, evocando a unicidade normativa que os une.

Apenas a título de exemplo, notamos que a função administrativa ordenadora, compreendida como "o conjunto de poderes para editar regras, produzir decisões e promover sua execução concreta visando a conformar, dentro de certos limites, liberdades e direitos individuais, como meio de produzir a harmonia social $[\ldots]^{\prime 10}$, atua na seara ambiental por meio do estabelecimento de restrições à atividade privada e do poder de polícia administrativa, ressaltando o caráter repressivo da legislação ambiental. Como exemplo destas, podem ser citados os espaços territoriais especialmente protegidos (unidades de conservação, reservas legais, áreas de proteção permanente etc.), o estabelecimento de normas relativos a padrões de qualidade ambiental e manejo de recursos ambientais, a fiscalização e aplicação de sanções ambientais, entre outros.

Esse exemplo corrobora a existência de uma unicidade normativa do direito. Não obstante às diversas disciplinas jurídicas seja atribuída uma relativa autonomia (didático-científica), compõem elas um ordenamento jurídico único, atuando conjuntamente.

Mesmo considerando a íntima relação entre o regime jurídico administrativo e o Direito Ambiental, o que se nota no discurso da doutrina jusambientalista explicitado na quase totalidade de cursos e manuais da disciplina - é que, em regra, se omite a supremacia do interesse público como princípio em razão de que este é inerente a toda ação administrativa e por isso não cabe menção como princípio do direito ambiental, o que parece justificável. Nesse caso, a omissão do

\footnotetext{
10 JUSTEN FILHO, Marçal. Curso de Direito Administrativo: São Paulo: Saraiva, 2005, p. 33.
} 
KRUBNIKI, João Pedro Ruppert. A supremacia do interesse público como princípio do Direito Ambiental. Revista Eletrônica Direito e Política, Programa de Pós-Graduação Stricto Sensu em Ciência Jurídica da UNIVALI, Itajaí, v.13, n.2, $2^{\circ}$ quadrimestre de 2018. Disponível em: www.univali.br/direitoepolitica - ISSN 1980-7791

princípio não deixa de considerá-lo implícito, mesmo que debatido em outro ramo do direito.

Entretanto, posicionamento passível de suscitar maior debate é aquele que vem a sustentar que o direito ambiental trata de interesses difusos, os quais não devem ser confundidos com os interesses públicos, o que acaba afastando o princípio da supremacia do interesse público e cedendo espaço ao princípio da proporcionalidade. Exemplificando essa posição, pode-se citar Luis Paulo Sirvinskas que, embora reconheça o princípio da supremacia do interesse público no Direito Ambiental ${ }^{11}$, defende que "os interesses defendidos por esse novel ramo do direito não pertencem à categoria de interesse público (direito público) nem de interesse privado (direito privado). [...] São interesses dispersos ou difusos situado numa zona intermediária entre o público e o privado"12.

Para parte da doutrina, a eventual primazia do meio ambiente sobre outros direitos não decorre de razões dogmático-jurídicas, nem do princípio da supremacia do interesse público (pois estrema estes dos interesses difusos, incluindo-se o meio ambiente ${ }^{13}$, mas sim de um sopesamento hermenêutico que requer uma "intensa atividade" do intérprete, o qual deve ponderar os interesses numa balança hipotética ${ }^{14}$.

Entretanto, o questionamento do princípio da supremacia do interesse público, com a consequente valorização do princípio da proporcionalidade não é uma novidade instaurada no âmbito do Direito Ambiental, já encontrando ampla discussão no âmbito do Direito Administrativo, a qual, contudo, parece não ser

\footnotetext{
${ }^{11}$ SIRVINSKAS, Luís Paulo. Manual de direito ambiental. 13. ed. São Paulo: Saraiva, 2013, p. 250.

12 SIRVINSKAS, Luís Paulo. Manual de direito ambiental, p. 96.

${ }^{13}$ BELCHIOR, Germana Parente Neiva; KRELL, Andreas J. . Os princípios da ponderação e da proporcionalidade: instrumentos para solucionar conflitos normativos que envolvem o direito fundamental a um meio ambiente sadio. In: XVIII Congresso Nacional do CONPEDI, 2009, São Paulo. XVIII Congresso Nacional do CONPEDI. Estado Globalização e Soberania: o direito do século XXI. Florianópolis: Fundação Boiteux, 2009. v. 18. p. 2720.
}

14 BELCHIOR, Germana Parente Neiva; KRELL, Andreas J. XVIII Congresso Nacional do CONPEDI, p. 2723. 
KRUBNIKI, João Pedro Ruppert. A supremacia do interesse público como princípio do Direito Ambiental. Revista Eletrônica Direito e Política, Programa de Pós-Graduação Stricto Sensu em Ciência Jurídica da UNIVALI, Itajaí, v.13, n.2, $2^{\circ}$ quadrimestre de 2018. Disponível em: www.univali.br/direitoepolitica - ISSN 1980-7791

reproduzida nas discussões jusambientalistas. Os tópicos subsequentes buscam realizar essa aproximação.

\section{O SUPOSTO CARÁTER AUTORITÁRIO DO DIREITO ADMINISTRATIVO E OS ATAQUES À NOÇÃO DE INTERESSE PÚBLICO.}

No âmbito da doutrina administrativista, a partir da publicação de artigo de Humberto Ávila ${ }^{15}$, originou-se controvérsia relativa a eventual superação do princípio da supremacia do interesse público, que viria a ser substituído pelo princípio da proporcionalidade. Para o autor, a supremacia do interesse público não se configuraria como uma norma-princípio ${ }^{16}$, de modo que a Administração Pública não poderia impor restrições ou obrigações aos particulares a partir desse fundamento ${ }^{17}$.

Sobre a configuração do interesse público, Ávila sustenta que:

[...] mesmo nos casos em que ele legitima uma atuação estatal restritiva específica, deve haver uma ponderação relativamente aos interesses privados e à medida de sua restrição. É essa ponderação para atribuir máxima realização aos direitos envolvidos o critério decisivo para a atuação administrativa. E antes que esse critério seja delimitado, não há cogitar sobre a referida supremacia do interesse público sobre 0 particular. ${ }^{18}$

Para os defensores dessa corrente, a crise dos paradigmas do direito administrativo (dentre os quais se destaca supremacia do interesse público sobre o privado) não é nova, mas um vício de origem que remete ao século XIX.

Assim, para Gustavo Binenbojm, o surgimento do direito administrativo, e de todas suas categorias jurídicas peculiares (supremacia do interesse público,

\footnotetext{
15 ÁVILA, Humberto. Repensando o princípio da supremacia do interesse público sobre o particular. Revista Trimestral de Direito Público. São Paulo: Malheiros, 1999, v. 24, p. 159-180.

16 ÁVILA, Humberto. Revista Trimestral de Direito Público, p. 165.

17 ÁVILA, Humberto. Revista Trimestral de Direito Público, p. 180.

18 ÁVILA, Humberto. Repensando o princípio da supremacia do interesse público sobre o particular.
} Revista Trimestral de Direito Público. São Paulo: Malheiros, 1999, v. 24, p. 215. 
KRUBNIKI, João Pedro Ruppert. A supremacia do interesse público como princípio do Direito Ambiental. Revista Eletrônica Direito e Política, Programa de Pós-Graduação Stricto Sensu em Ciência Jurídica da UNIVALI, Itajaí, v.13, n.2, $2^{\circ}$ quadrimestre de 2018. Disponível em: www.univali.br/direitoepolitica - ISSN 1980-7791

prerrogativas da Administração, discricionariedade, etc.), representou uma forma de reprodução e sobrevivência das práticas administrativas do Antigo Regime, e não sua pura superação. Nessa perspectiva, a criação de um direito especial da Administração Pública teria resultado não da vontade geral, mas de decisão autovinculativa do próprio Executivo, através do Conseil d'État francês ${ }^{19}$.

Também para Paulo Otero, "a invocação do princípio da separação de poderes foi um simples pretexto para que, visando um objectivo político concreto de garantir um efectivo alargamento da esfera de liberdade decisória da Administração Pública"20. Nessa linha de pensamento, o Estado Social teria sublinhado e agravado "o descompasso entre as velhas categorias e as reais necessidades e expectativas das sociedades contemporâneas em relação à Administração Pública"21.

Disso decorre, para Binenbojm, o dever de proporcionalidade como fundamento e técnica da decisão administrativa, em substituição ao princípio da supremacia do interesse público. O autor não nega o conceito de interesse público, mas afirma que este "comporta, desde a sua configuração constitucional, uma imbricação entre interesses difusos da coletividade e interesses individuais e particulares, não se podendo estabelecer a prevalência teórica e antecipada de uns sobre os outros"22.

Esse posicionamento se mostra em consonância com a parcela da doutrina jusambientalista supracitada, que considera que a eventual primazia do meio ambiente sobre outros direitos não decorre de razões dogmático-jurídicas, nem do

19 BINEBOJM, Gustavo. Da supremacia do interesse público ao dever de proporcionalidade: um novo paradigma para o Direito Administrativo. In: SARMENTO, Daniel (Org.). Interesses públicos versus interesses privados: descontruindo o princípio da supremacia do interesse público. Rio de Janeiro: Lumen Juris, 2005, p. 126.

20 OTERO, Paulo. Legalidade e Administração pública: o sentido da vinculação administrativa à juridicidade. Coimbra: Alamedina, 2003, p. 275.

21 BINEBOJM, Gustavo, Interesses públicos versus interesses privados: descontruindo o princípio da supremacia do interesse público, p. 126.

22 BINEBOJM, Gustavo. Da supremacia do interesse público ao dever de proporcionalidade: um novo paradigma para o Direito Administrativo. In: SARMENTO, Daniel (Org.). Interesses públicos versus interesses privados: descontruindo o princípio da supremacia do interesse público. Rio de Janeiro: Lumen Juris, 2005, p. 149. 
KRUBNIKI, João Pedro Ruppert. A supremacia do interesse público como princípio do Direito Ambiental. Revista Eletrônica Direito e Política, Programa de Pós-Graduação Stricto Sensu em Ciência Jurídica da UNIVALI, Itajaí, v.13, n.2, $2^{\circ}$ quadrimestre de 2018. Disponível em: www.univali.br/direitoepolitica - ISSN 1980-7791

princípio da supremacia do interesse público (pois estrema estes dos interesses difusos, incluindo-se o meio ambiente ${ }^{23}$ ), mas sim de um sopesamento hermenêutico que requer uma "intensa atividade" do intérprete, o qual deve ponderar os interesses numa balança hipotética 24 .

Ademais, na discussão gerada no âmbito da doutrina administrativista, tem se defendido que a aplicação do princípio supremacia do interesse público sobre o privado tem possibilitado "a emergência de uma política autoritária de realização constitucional, onde os direitos, liberdades e garantias fundamentais devem, sempre e sempre, ceder aos reclames do Estado"25. Em resumo, para essa posição,

[...] a Administração Pública deve buscar utilizar-se da ponderação para superar as regras de preferência estáticas atuando situativa e estrategicamente com vistas à formulação de certos standards de decisão. Tais standards permitem a flexibilização das decisões administrativas de acordo com as peculiaridades do caso concreto, mas evitam o mal reverso, que é a incerteza jurídica total provocada por juízos de ponderação discricionários produzidos caso a caso. ${ }^{26}$

Em sentido contrário, outra parcela da doutrina sustenta que a interpretação supracitada recusa a importância tanto do aspecto real quando da face simbólica da legislação revolucionária e do pensamento liberal francês ${ }^{27}$. Nessa linha de pensamento, se demonstra como:

23 BELCHIOR, Germana Parente Neiva; KRELL, Andreas J. . Os princípios da ponderação e da proporcionalidade: instrumentos para solucionar conflitos normativos que env olvem 0 direito fundamental a um meio ambiente sadio. In: XVIII Congresso Nacional do CONPEDI, 2009, São Paulo. XVIII Congresso Nacional do CONPEDI. Estado Globalização e Soberania: o direito do século XXI. Florianópolis: Fundação Boiteux, 2009. v. 18, p. 2720.

24 BELCHIOR, Germana Parente Neiva; KRELL, Andreas J. XVIII Congresso Nacional do CONPEDI, p. 2723.

25 SCHIER, Paulo Ricardo. Ensaio sobre a Supremacia do Interesse Público sobre o Privado e o Regime Jurídico dos Direitos Fundamentais. IN: SARMENTO, Daniel (Org.). Interesses públicos versus interesses privados: descontruindo o princípio de supremacia do interesse público. Rio de Janeiro: Lumen Juris, 2007, p. 218-219.

26 BINEBOJM, Gustavo. Interesses públicos versus interesses privados: descontruindo o princípio da supremacia do interesse público, p. 150.

27 GABARDO, Emerson; HACHEM, Daniel Wunder. O suposto caráter autoritário da supremacia do interesse público e das origens do direito administrativo: uma crítica da crítica. In: BACELLAR FILHO, 
KRUBNIKI, João Pedro Ruppert. A supremacia do interesse público como princípio do Direito Ambiental. Revista Eletrônica Direito e Política, Programa de Pós-Graduação Stricto Sensu em Ciência Jurídica da UNIVALI, Itajaí, v.13, n.2, $2^{\circ}$ quadrimestre de 2018. Disponível em: www.univali.br/direitoepolitica - ISSN 1980-7791

- Direito Administrativo não possui raízes autoritárias justamente por ser um contraponto axiológico ao regime anterior, somente tendo sido realmente cultivado depois que seus princípios passaram a ser deduzidos da natureza do homem e da sociedade e não do poder divino ${ }^{28}$.

Essa corrente contrapõe diversos argumentos às críticas ao interesse público e sua supremacia. Primeiro, traça a distinção entre a noção de interesse público quando do surgimento do direito administrativo no Estado Liberal (no qual o interesse público coincidia com o individualismo e abstencionismo estatal e, portanto, aos direitos fundamentais de matriz liberal) e a noção de interesse público presente no Estado Social (no qual o interesse público se vincula à satisfação dos direitos fundamentais, em especial os direitos econômicos e sociais) ${ }^{29}$.

A partir dessas considerações, se reconhece a caracterização constitucional do princípio da supremacia do interesse público (deduzido dos arts. 30, IV e 66, §10 da CR/88), e que autoriza "a atribuição das prerrogativas à Administração Pública, para fazer prevalecer o interesse geral quando isso se fizer necessário"30.

Quando da aplicação desse princípio, deve ser observada a existência de um sentido amplo e um sentido estrito de interesse público. Em sua amplitude, o interesse público abrange todos os interesses garantidos pelo sistema normativo (direitos subjetivos e interesses legítimos, sejam eles de natureza individual, coletiva ou difusa), ao passo que em seu sentido estrito se refere àquele interesse cuja identificação é efetuada pelo Estado no caso concreto. Este último é, em

Romeu F.; HACHEM, Daniel W. (Coords.). Direito Administrativo e Interesse público. Belo Horizonte: Fórum, 2010, p. 158.

28 GABARDO, Emerson; HACHEM, Daniel Wunder. O suposto caráter autoritário da supremacia do interesse público e das origens do direito administrativo: uma crítica da crítica. In: BACELLAR FILHO, Romeu F.; HACHEM, Daniel W. (Coords.). Direito Administrativo e Interesse público. Belo Horizonte: Fórum, 2010, p. 170.

29 GABARDO, Emerson; HACHEM, Daniel Wunder. O suposto caráter autoritário da supremacia do interesse público e das origens do direito administrativo: uma crítica da crítica. In: BACELLAR FILHO, Romeu F.; HACHEM, Daniel W. (Coords.). Direito Administrativo e Interesse público. Belo Horizonte: Fórum, 2010, p. 172-173.

30 HACHEM, Daniel. Princípio constitucional da supremacia do interesse público. Belo Horizonte: Fórum, 2011, p. 373. 
KRUBNIKI, João Pedro Ruppert. A supremacia do interesse público como princípio do Direito Ambiental. Revista Eletrônica Direito e Política, Programa de Pós-Graduação Stricto Sensu em Ciência Jurídica da UNIVALI, Itajaí, v.13, n.2, $2^{\circ}$ quadrimestre de 2018. Disponível em: www.univali.br/direitoepolitica - ISSN 1980-7791

regra, utilizado para instituir proibições, limitações a direitos ou coações, que sejam impostas unilateralmente pelo Estado; como pressuposto para concessão de autorizações, que serão denegadas se ofensivas ao interesse geral; ou para justificar modificações ou extinções de atos ou relações jurídicas já estabelecidas. ${ }^{31}$

Especificamente no tocante à aplicação do princípio da supremacia, as colisões de interesses capazes de ser resolvidas pela aplicação do mesmo podem ser de duas ordens: entre um interesse juridicamente resguardado e outro não tutelado pelo Direito positivo ou entre dois interesses albergados pelo sistema normativo, sendo um deles atinente à coletividade em si mesma considerada e outro relativo a interesses de indivíduos ou grupos determinados. ${ }^{32}$

No primeiro caso (em que colidem o interesse público em sentido amplo e interesses não tutelados), o princípio da supremacia do interesse público é aplicado de forma que o interesse público prevaleça de maneira absoluta. No segundo caso, a aplicação depende das circunstâncias do caso concreto, devendo ser observados alguns requisitos para a aplicação do princípio, quais sejam:

(a) existência de previsão normativa específica, instituindo uma competência jurídica; (b) dever de motivação; (c) respeito às demais sujeições especiais do regime jurídicoadministrativo; (d) garantia de uma compensação jurídica, quando a aplicação do princípio provocar um dano anormal e especial. ${ }^{33}$

Ao estabelecer os critérios para a correta aplicação do princípio da supremacia do interesse público, essa visão acaba por afastar o argumento de que o princípio da proporcionalidade seria mais adequado à aplicação dos direitos fundamentais. É o interesse público que legitima e limita o exercício de poder. Nas palavras de

31 HACHEM, Daniel. Princípio constitucional da supremacia do interesse público. Belo Horizonte: Fórum, 2011, p. 183.

32 HACHEM, Daniel. Princípio constitucional da supremacia do interesse público, p. 195.

${ }^{33}$ HACHEM, Daniel. Princípio constitucional da supremacia do interesse público, p. 206. 
KRUBNIKI, João Pedro Ruppert. A supremacia do interesse público como princípio do Direito Ambiental. Revista Eletrônica Direito e Política, Programa de Pós-Graduação Stricto Sensu em Ciência Jurídica da UNIVALI, Itajaí, v.13, n.2, $2^{\circ}$ quadrimestre de 2018. Disponível em: www.univali.br/direitoepolitica - ISSN 1980-7791

Hachem, "as prerrogativas e sujeições especiais da Administração encontram a sua razão de ser no interesse público que as justifica"34.

A partir desse debate, Fernando Dias Menezes de Almeida compreende haver, no Brasil, uma divisão doutrinária entre a denominada escola do interesse público, que se conecta mais intensamente com um modo francês de enxergar o direito administrativo pelo viés de um regime jurídico e prerrogativas e sujeições, construído em função das peculiaridades da administração como sujeito de direito, e a denominada corrente liberal-subjetivista se conecta mais diretamente com o pensamento alemão pós-guerra de fundamentalidade dos direitos fundamentais, que acaba por valorizar o princípio da proporcionalidade ${ }^{35}$.

Para Di Pietro, contudo, não há um antagonismo entre o interesse público e os direitos fundamentais. A autora entende ser possível defender a existência do princípio da supremacia do interesse público e seu fundamento constitucional, sem ser enquadrado na chamada Escola Estatizante, a partir do reconhecimento da coexistência, no ordenamento jurídico brasileiro, da centralidade da pessoa humana e da proteção predominante do interesse público, quando haja fundamento constitucional para tanto ${ }^{36}$.

Refutando a corrente que defende a substituição do princípio da supremacia do interesse público, sustenta que

Não assiste razão à corrente que de repente passou a entender que existe um antagonismo entre os direitos individuais, garantidos na Constituição, e o princípio da supremacia do interesse público. Não vejo razão para a formulação de duas correntes uma que privilegia o interesse público e outra que privilegia os direitos fundamentais. As

${ }^{34}$ HACHEM, Daniel. Princípio constitucional da supremacia do interesse público, p. 115.

35 ALMEIDA, Fernando Menezes Dias de. Formação da Teoria do Direito Administrativo Brasileiro. Rio de Janeiro: Quartier Latin, 2015, p. 399-400.

36 DI PIETRO, Maria Sylvia Zanella. Supremacia do Interesse Público e a questão dos direitos fundamentais. IN: BLANCHET, Luiz Alberto; HACHEM, Daniel Wunder; SANTANO, Ana Cláudia. Estado, direito e políticas públicas: homenagem ao professor Romeu Felipe Bacellar Filho. Curitiba: Íthala, 2014, p. 25. 
KRUBNIKI, João Pedro Ruppert. A supremacia do interesse público como princípio do Direito Ambiental. Revista Eletrônica Direito e Política, Programa de Pós-Graduação Stricto Sensu em Ciência Jurídica da UNIVALI, Itajaí, v.13, n.2, $2^{\circ}$ quadrimestre de 2018. Disponível em: www.univali.br/direitoepolitica - ISSN 1980-7791

duas ideias estão e sempre estiveram presentes no direito administrativo, desde as suas origens. ${ }^{37}$

Nos parece assistir razão a essa corrente que contraria o caráter autoritário do princípio da supremacia do interesse público e nega a sua incompatibilidade com a proteção dos direitos fundamentais. No que diz respeito à necessidade de ponderação, para que certos interesses não prevaleçam de maneira absoluta sobre outros, dois pontos merecem maior atenção: Primeiro, que a exigência de utilização de critérios de intepretação esteve historicamente presente na aplicação do princípio da supremacia do interesse público, exigindo proporção entre os fins que dizem respeito ao interesse público (e não aos interesses privados) ${ }^{38}$.

Segundo, como já se demonstrou, aplicação do princípio em hipótese de conflito entre interesses juridicamente depende da análise das circunstâncias do caso concreto, devendo ser observados alguns requisitos para a aplicação do princípio, quais sejam a existência de previsão normativa específica, instituindo uma competência jurídica, o dever de motivação, o respeito às demais sujeições especiais do regime jurídico-administrativo e a garantia de uma compensação jurídica, quando a aplicação do princípio provocar um dano anormal e especial. ${ }^{39}$

Esse debate, originário do Direito Administrativo, parece ter recebido pouca atenção de outras disciplinas jurídicas. Não obstante, as posições dele originadas parecem ter se reproduzido, sem maiores discussões e subjacentes a outros argumentos, a outros ramos do direito, como é o caso do Direito Ambiental.

37 DI PIETRO, Maria Sylvia Zanella. Supremacia do Interesse Público e a questão dos direitos fundamentais. IN: BLANCHET, Luiz Alberto; HACHEM, Daniel Wunder; SANTANO, Ana Cláudia. Estado, direito e políticas públicas: homenagem ao professor Romeu Felipe Bacellar Filho. Curitiba: Íthala, 2014, p. 34.

38 DI PIETRO, Maria Sylvia Zanella. O princípio da supremacia do interesse público - sobrevivência diante dos ideais do neoliberalismo. IN: BACELLAR FILHO; Romeu Felipe; HACHEM, Daniel Wunder (Coords.). Direito Administrativo e Interesse Público: Estudos em Homenagem ao professor Celso Antônio Bandeira de Mello. Belo Horizonte: Fórum, 2010, p. 217.

39 HACHEM, Daniel. Princípio constitucional da supremacia do interesse público. Belo Horizonte: Fórum, 2011, p. 206. 
KRUBNIKI, João Pedro Ruppert. A supremacia do interesse público como princípio do Direito Ambiental. Revista Eletrônica Direito e Política, Programa de Pós-Graduação Stricto Sensu em Ciência Jurídica da UNIVALI, Itajaí, v.13, n.2, $2^{\circ}$ quadrimestre de 2018. Disponível em: www.univali.br/direitoepolitica - ISSN 1980-7791

\section{A RELAÇÃo ENTRE OS INTERESSES PÚBLICOS E DIFUSOS E A SUPREMACIA DO INTERESSE PÚBLICO COMO PRINCÍPIO DO DIREITO AMBIENTAL}

Frente ao relativamente grande aparato da Administração Pública em defesa do meio ambiente, é de se questionar o porquê de a doutrina jusambientalista omitir ou relativizar o princípio da supremacia do interesse público sobre o privado como um dos princípios do Direito Ambiental, muitas vezes cedendo espaço ao princípio da proporcionalidade.

Como já se referiu, o que se nota no discurso da doutrina jusambientalista é que, em regra, se omite a supremacia do interesse público como princípio em razão de que este é inerente a toda ação administrativa e por isso não cabe menção como princípio do direito ambiental, o que parece justificável. Nesse caso, a omissão do princípio não deixa de considerá-lo implícito, mesmo que debatido em outro ramo do direito.

Entretanto, o posicionamento passível de suscitar maior debate é aquele que vem a sustentar que o direito ambiental trata de interesses difusos, os quais não devem ser confundidos com os interesses públicos, o que acaba afastando o princípio da supremacia do interesse público e cedendo espaço ao princípio da proporcionalidade.

Exemplificando essa posição, cita-se Luis Paulo Sirvinskas que, embora reconheça o princípio da supremacia do interesse público no Direito Ambiental ${ }^{40}$, defende que "os interesses defendidos por esse novel ramo do direito não pertencem à categoria de interesse público (direito público) nem de interesse privado (direito privado). [...] São interesses dispersos ou difusos situado numa zona intermediária entre o público e o privado"41.

\footnotetext{
40 SIRVINSKAS, Luís Paulo. Manual de direito ambiental. 13. ed. São Paulo: Saraiva, 2013, p. 250.

${ }^{41}$ SIRVINSKAS, Luís Paulo. Manual de direito ambiental, p. 93.
} 
KRUBNIKI, João Pedro Ruppert. A supremacia do interesse público como princípio do Direito Ambiental. Revista Eletrônica Direito e Política, Programa de Pós-Graduação Stricto Sensu em Ciência Jurídica da UNIVALI, Itajaí, v.13, n.2, $2^{\circ}$ quadrimestre de 2018. Disponível em: www.univali.br/direitoepolitica - ISSN 1980-7791

A relação entre os interesses ou direitos públicos e os interesses ou direitos difusos enseja discussões desde longa data. Com efeito, desde a segunda metade do século XX se encontram referências doutrinárias que apontam para o fato de que "a instabilidade da definição e o esmaecimento dos contornos do interesse difuso se acentuam quando o cotejamos com o interesse público"42.

Para parte da doutrina, os interesses difusos se situariam entre os interesses públicos e privados e, para outra, seriam espécies dos interesses públicos. Ocorre que a natureza e taxionomia desses interesses não se limita a uma discussão doutrinária, produzindo efeitos práticos, dentre os quais destacamos, no presente artigo, a vinculação, ou não, ao princípio da supremacia do interesse público.

Como consequência da omissão ou má compreensão do princípio da supremacia do interesse público no Direito Ambiental, pode se notar a ascensão da importância conferida ao princípio da proporcionalidade ou do princípio do sopesamento ou ponderação. Parte da doutrina afirma que o meio ambiente possui uma primariedade relativa quando em confronto com outros interesses ou direitos, mas que isso não decorre de uma hierarquia dogmática-jurídica ou da supremacia do interesse público sobre o privado, mas sim da aplicação do princípio do sopesamento ou ponderação, com a justificativa de que "não há vida (assim como os outros direitos) se não houver planeta"43.

Tem se sustentado que há uma "conflituositá massima inerente aos interesses metaindividuais, traduzida na facilidade com que se contrapõem uns aos outros no caso concreto, bem como a outros interesses individuais" ${ }^{44}$, de modo que a solução desses conflitos não pode ser resolvida pelo estabelecimento de uma hierarquia

\footnotetext{
42 FERRAZ, Antonio Augusto Mello de Camargo de. Interesse Público, Interesse Difuso e Defesa do Consumidor. Revista Justitia. São Paulo, v. 60, 1999, p. 49.

43 BELCHIOR, Germana Parente Neiva. Fundamentos epistemológicos do Direito Ambiental. 306 p. Tese de Doutorado - Universidade Federal de Santa Catarina. Florianópolis, 2015,_p. 142-143

44 OLIVEIRA, B. L. Proporcionalidade no direito ambiental. In LIVIANU, R., cood. Justiça, cidadania e democracia. Rio de Janeiro: Centro Edelstein de Pesquisa Social, 2009, p. 64.
} 
KRUBNIKI, João Pedro Ruppert. A supremacia do interesse público como princípio do Direito Ambiental. Revista Eletrônica Direito e Política, Programa de Pós-Graduação Stricto Sensu em Ciência Jurídica da UNIVALI, Itajaí, v.13, n.2, $2^{\circ}$ quadrimestre de 2018. Disponível em: www.univali.br/direitoepolitica - ISSN 1980-7791

entre os diversos interesses, mas sim pela ponderação, caso a caso, dos mesmos $^{45}$.

Desse modo, a confusão conceitual existente entre os interesses públicos e os difusos faz com que o princípio da supremacia do interesse público não seja, em regra, elencado como princípio do Direito Ambiental nos manuais e artigos acadêmicos, cedendo espaço ao princípio da proporcionalidade e/ou da ponderação.

Em sentido contrário, parcela da doutrina, que não debate a distinção entre interesses públicos e difusos, admite implícita ou explicitamente o princípio da supremacia do interesse público no Direito Ambiental. Deste lado se situam os autores $^{46}$ que defendem que Direito Administrativo fornece a espinha dorsal e a principiologia fundamental do Direito Ambiental, de modo que "qualquer que seja a área de atuação do Poder Público, sempre prevalecerá a supremacia e a indisponibilidade do interesse público em relação aos interesses privados, exigindo-se, sempre, a intervenção estatal obrigatória nessas áreas"47.

Parece prevalecer esse entendimento, majoritariamente acolhido, em razão de que a primazia da proteção ao meio ambiente não decorre de uma aplicação do princípio da ponderação ou da proporcionalidade, como se tem sustentado em parcela da doutrina, mas sim do princípio da supremacia do interesse público, que não pode ser confundido com a prevalência absoluta de certos interesses sobre outros juridicamente tutelados. Com efeito, assim como no Direito Administrativo, os argumentos a favor do princípio da proporcionalidade no Direito Ambiental também são pautados na crença da impossibilidade de se estabelecer uma primazia prévia e absoluta de qualquer direito, mesmo que fundamental. Esses argumentos convergem com a noção de que o interesse público "comporta, desde

\footnotetext{
45 OLIVEIRA, B. L. Justiça, cidadania e democracia, p. 66.

46 Tais como MILARÉ, Édis. Direito do Ambiente: A gestão ambiental em foco: doutrina, jurisprudência, glossário.6. ed. Ver, atual e ampl. RT, São Paulo, 2009, p. 837

47 Figueiredo, Guilherme José Purvin de. Curso de Direito Ambiental. 6. ed., rev., atual. e ampl. São Paulo: RT, 2013, p. 137
} 
KRUBNIKI, João Pedro Ruppert. A supremacia do interesse público como princípio do Direito Ambiental. Revista Eletrônica Direito e Política, Programa de Pós-Graduação Stricto Sensu em Ciência Jurídica da UNIVALI, Itajaí, v.13, n.2, $2^{\circ}$ quadrimestre de 2018. Disponível em: www.univali.br/direitoepolitica - ISSN 1980-7791

a sua configuração constitucional, uma imbricação entre interesses difusos da coletividade e interesses individuais e particulares, não se podendo estabelecer a prevalência teórica e antecipada de uns sobre os outros"48.

Tem se sustentado, e com razão, que a alteração do papel do Estado, na transição do Estado liberal ao Estado Social, provocou o surgimento da tutela de interesses coletivos e difusos, metaindividuais. Entretanto, essa constatação parece levar parte da doutrina à conclusão de que esses interesses vieram a substituir ou complementar o interesse público, ocupando lugar por este não abrangido. Trazendo uma possibilidade de resolver a questão, Hugo Nigro Mazzilli busca esclarecer as dúvidas que pairam sobre a relação entre os interesses públicos e difusos, demonstrando que:

Há interesses difusos a) tão abrangentes que chegam a coincidir com o interesse público (como o do meio ambiente como um todo); b) menos abrangentes que o interesse público, por dizerem respeito a um grupo disperso, mas que não se confundem com o interesse geral da coletividade (como o dos consumidores de um produto); c) em conflito com o interesse da coletividade como um todo (como os interesses dos trabalhadores na indústria do tabaco); d) em conflito com os interesses do Estado, enquanto pessoa jurídica (como o interesse dos contribuintes); e) atinentes a grupos que mantém conflitos entre si (interesses transindividuais reciprocamente conflitantes $[\ldots])^{49}$

O autor prossegue com o raciocínio ao sustentar que:

Não são, pois, os interesses difusos mera subespécie de interesse público. Embora em muitos casos possa até coincidir o interesse de um grupo indeterminável de pessoas com o interesse do Estado com o interesse da sociedade como um todo (como o interesse ao meio ambiente sadio), a verdade é

\footnotetext{
48 BINEBOJM, Gustavo. Da supremacia do interesse público ao dever de proporcionalidade: um novo paradigma para o Direito Administrativo. In: SARMENTO, Daniel (Org.). Interesses públicos versus interesses privados: descontruindo o princípio da supremacia do interesse público. Rio de Janeiro: Lumen Juris, 2005, p. 149.
}

49 MAZZILLI, Hugo Nigro. A defesa dos interesses difusos em juízo. 21. ed., rev., atual. e ampl. São Paulo: Saraiva, 2008, p. 53. 
KRUBNIKI, João Pedro Ruppert. A supremacia do interesse público como princípio do Direito Ambiental. Revista Eletrônica Direito e Política, Programa de Pós-Graduação Stricto Sensu em Ciência Jurídica da UNIVALI, Itajaí, v.13, n.2, $2^{\circ}$ quadrimestre de 2018. Disponível em: www.univali.br/direitoepolitica - ISSN 1980-7791

que nem todos os interesses difusos são compartilhados pela coletividade ou comungados pelo Estado ${ }^{50}$

Essa concepção permite afirmar que o meio ambiente é um interesse difuso coincidente com o interesse público, razão pela qual, ao se aceitar a supremacia do interesse público como princípio do regime jurídico administrativo, a natureza difusa do meio ambiente não teria o condão de afastar o princípio da supremacia do interesse público sobre o privado. Portanto, com base nesse entendimento, se busca demonstrar que a supremacia do interesse público se caracteriza como um princípio do Direito Ambiental, encontrando, inclusive, suporte constitucional.

Assim, a supremacia do interesse público só resta afastada caso se entenda (como o faz parte da doutrina administrativista) que a supremacia do interesse público fora substituída pelo princípio da proporcionalidade, ou caso se adote uma posição que compreenda haver um hiato entre os interesses difusos e os interesses públicos, de modo que o meio ambiente não estaria compreendido nesta última categoria, sujeitando-se a um regime diferenciado.

Em consonância com a doutrina administrativista que entende haver caracterização constitucional do princípio da supremacia do interesse público (deduzido dos arts. 30, IV e 66, $\S 1^{0}$ da CR/88), e que autoriza "a atribuição das prerrogativas à Administração Pública, para fazer prevalecer o interesse geral quando isso se fizer necessário" 51 , nos parece que o fundamento constitucional do princípio da supremacia do interesse público sobre o privado impõe que ele seja aplicado também ao Direito Ambiental.

A relativa autonomia da disciplina, que é apenas didático-científica, e não normativa, faz com que este esteja sujeito a influxos gerais do ordenamento jurídico, de modo que sua autonomia é restrita a determinado espaço, não podendo avançar contra preceitos constitucionais.

50 MAZZILLI, Hugo Nigro. A defesa dos interesses difusos em juízo, p. 54.

51 HACHEM, Daniel. Princípio constitucional da supremacia do interesse público. Belo Horizonte: Fórum, 2011, p. 373. 
KRUBNIKI, João Pedro Ruppert. A supremacia do interesse público como princípio do Direito Ambiental. Revista Eletrônica Direito e Política, Programa de Pós-Graduação Stricto Sensu em Ciência Jurídica da UNIVALI, Itajaí, v.13, n.2, $2^{\circ}$ quadrimestre de 2018. Disponível em: www.univali.br/direitoepolitica - ISSN 1980-7791

Desse modo, se faz necessário consolidar o entendimento de que não há uma incompatibilidade da supremacia do interesse público com a proteção dos direitos fundamentais. Ademais, esse princípio só é aplicado de maneira absoluta nos casos em que colidem o interesse público em sentido amplo e interesses não tutelados. Quando colidirem dois ou mais interesses juridicamente tutelados, a aplicação depende das circunstâncias do caso concreto, devendo ser observados alguns requisitos para a aplicação do princípio.

Consequência da correta aplicação do princípio, diversos atos jurídicos relativos ao Direito Ambiental, como a criação de espaços territoriais especialmente protegidos, o estabelecimento de normas relativos a padrões de qualidade ambiental e manejo de recursos ambientais e a fiscalização e aplicação de sanções ambientais, são exercidos com a manutenção das prerrogativas especiais da Administração Pública, sem atribuir a isso um caráter autoritário, de modo a se recorrer à ponderação de interesses em todo caso concreto. É a supremacia do interesse público que permite ao Estado intervir em atividades privadas, e assim concretizar determinados fins, como a proteção do meio ambiente, respeitados, naturalmente, os direitos e garantias individuais. Assim, é necessário afastar, também na seara ambiental, o argumento oriundo da doutrina administrativista de que a supremacia do interesse público possuiria uma vertente autoritária, devendo ser substituída pelo princípio da proporcionalidade.

Desse modo, não se deve afirmar a incompatibilidade do princípio da supremacia do interesse público com a proteção de outros direitos fundamentais e até mesmo com o princípio da proporcionalidade. O princípio da supremacia do interesse público, por mais que seja pouco explorado na seara ambiental, possui uma aplicação análoga ao princípio in dubio pro natura, o que não significa que prevaleça de modo absoluto.

Reiterando o que se tem defendido no debate da doutrina administrativista, deve se afirmar que, no que diz respeito à necessidade de ponderação, para que certos interesses não prevaleçam de maneira absoluta sobre outros, dois pontos merecem atenção: Primeiro, que a exigência de utilização de critérios de intepretação esteve historicamente presente na aplicação do princípio da 
KRUBNIKI, João Pedro Ruppert. A supremacia do interesse público como princípio do Direito Ambiental. Revista Eletrônica Direito e Política, Programa de Pós-Graduação Stricto Sensu em Ciência Jurídica da UNIVALI, Itajaí, v.13, n.2, $2^{\circ}$ quadrimestre de 2018. Disponível em: www.univali.br/direitoepolitica - ISSN 1980-7791

supremacia do interesse público, exigindo proporção entre os fins que dizem respeito ao interesse público (e não aos interesses privados). $E$, segundo, a aplicação do princípio da supremacia do interesse público em hipótese de conflito entre interesses juridicamente relevantes depende da análise das circunstâncias do caso concreto, devendo ser observados alguns requisitos para a aplicação do princípio, quais sejam a existência de previsão normativa específica, instituindo uma competência jurídica, o dever de motivação, o respeito às demais sujeições especiais do regime jurídico-administrativo e a garantia de uma compensação jurídica, quando a aplicação do princípio provocar um dano anormal e especial ${ }^{52}$.

\section{CONSIDERAÇÕES FINAIS}

Diante de todo o exposto, pode-se concluir que, devido ao fato de grande parte da legislação ambiental possuir origem no Direito Administrativo, esta é norteada pelo regime jurídico administrativo e implementada através do exercício da função administrativa, razão pela qual a confusão conceitual dos direitos difusos e direito público e o discurso de vinculação dos direitos fundamentais ao princípio da proporcionalidade não justificam o afastamento do princípio da supremacia do interesse público, o qual encontra suporte constitucional.

A indeterminação entre os termos interesse público e interesse difuso contribui para a incompreensão da matéria, fazendo-se necessário se reafirmar a coexistência, no plano normativo, do princípio da supremacia do interesse público e da proporcionalidade. Ao se afirmar o meio ambiente como um interesse difuso coincidente com o interesse público, sua natureza difusa não teria o condão de afastar o princípio da supremacia do interesse público sobre o privado.

Portanto, mesmo que por vezes possa parecer óbvio - mas por vezes o deixa de ser, em razão de confusões conceituais e ataques ao princípio da supremacia do interesse público - é necessário se reafirmar as garantias da Administração Pública em sua atuação relativamente à proteção do meio ambiente, de modo que a relativa autonomia do Direito Ambiental em relação ao Direito Administrativo não

52 HACHEM, Daniel. Princípio constitucional da supremacia do interesse público. Belo Horizonte: Fórum, 2011, p. 183. 
KRUBNIKI, João Pedro Ruppert. A supremacia do interesse público como princípio do Direito Ambiental. Revista Eletrônica Direito e Política, Programa de Pós-Graduação Stricto Sensu em Ciência Jurídica da UNIVALI, Itajaí, v.13, n.2, $2^{\circ}$ quadrimestre de 2018. Disponível em: www.univali.br/direitoepolitica - ISSN 1980-7791

tenha o condão de aplicar o princípio da proporcionalidade em detrimento do princípio da supremacia do interesse público, mas afirme a coexistência normativa de ambos os princípios.

\section{REFERÊNCIA DAS FONTES CITADAS}

ALMEIDA, Fernando Menezes Dias de. Formação da Teoria do Direito Administrativo Brasileiro. Rio de Janeiro: Quartier Latin, 2015.

ANTUNES, Paulo de Bessa. Direito Ambiental. 12. ed. Rio de Janeiro: Lumen Juris, 2009.

ÁVILA, Humberto. Repensando o princípio da supremacia do interesse público sobre o particular. Revista Trimestral de Direito Público. São Paulo: Malheiros, 1999 , v. 24, p. 159-180.

BELCHIOR, Germana Parente Neiva. Fundamentos epistemológicos do Direito Ambiental. 306 p. Tese de Doutorado - Universidade Federal de Santa Catarina. Florianópolis, 2015.

BELCHIOR, Germana Parente Neiva; KRELL, Andreas J. . Os princípios da ponderação e da proporcionalidade: instrumentos para solucionar conflitos normativos que env olvem o direito fundamental a um meio ambiente sadio. In: XVIII Congresso Nacional do CONPEDI, 2009, São Paulo. XVIII Congresso Nacional do CONPEDI. Estado Globalização e Soberania: o direito do século XXI. Florianópolis: Fundação Boiteux, 2009. v. 18. p. 2709-2730.

BINEBOJM, Gustavo. Da supremacia do interesse público ao dever de proporcionalidade: um novo paradigma para o Direito Administrativo. In: SARMENTO, Daniel (Org.). Interesses públicos versus interesses privados: descontruindo o princípio da supremacia do interesse público. Rio de Janeiro: Lumen Juris, 2005, p. 117-169.

DI PIETRO, Maria Sylvia Zanella. O princípio da supremacia do interesse público sobrevivência diante dos ideais do neoliberalismo. IN: BACELLAR FILHO; Romeu Felipe; HACHEM, Daniel Wunder (Coords.). Direito Administrativo e Interesse Público: Estudos em Homenagem ao professor Celso Antônio Bandeira de Mello. Belo Horizonte: Fórum, 2010.

DI PIETRO, Maria Sylvia Zanella. Supremacia do Interesse Público e a questão dos direitos fundamentais. IN: BLANCHET, Luiz Alberto; HACHEM, Daniel Wunder; SANTANO, Ana Cláudia. Estado, direito e políticas públicas: homenagem ao professor Romeu Felipe Bacellar Filho. Curitiba: Íthala, 2014.

FERRAZ, Antonio Augusto Mello de Camargo de. Interesse Público, Interesse Difuso e Defesa do Consumidor. Revista Justitia. São Paulo, v. 60, 1999.

FIGUEIREDO, Guilherme José Purvin de. Curso de Direito Ambiental. 6. ed., rev., atual. e ampl. São Paulo: RT, 2013. 
KRUBNIKI, João Pedro Ruppert. A supremacia do interesse público como princípio do Direito Ambiental. Revista Eletrônica Direito e Política, Programa de Pós-Graduação Stricto Sensu em Ciência Jurídica da UNIVALI, Itajaí, v.13, n.2, $2^{\circ}$ quadrimestre de 2018. Disponível em: www.univali.br/direitoepolitica - ISSN 1980-7791

GABARDO, Emerson; HACHEM, Daniel Wunder. O suposto caráter autoritário da supremacia do interesse público e das origens do direito administrativo: uma crítica da crítica. In: BACELLAR FILHO, Romeu F.; HACHEM, Daniel W. (Coords.). Direito Administrativo e Interesse público. Belo Horizonte: Fórum, 2010.

HACHEM, Daniel. Princípio constitucional da supremacia do interesse público. Belo Horizonte: Fórum, 2011.

JUSTEN FILHO, Marçal. Curso de Direito Administrativo: São Paulo: Saraiva, 2005.

MAZZILLI, Hugo Nigro. A defesa dos interesses difusos em juízo. 21. ed., rev., atual. e ampl. São Paulo: Saraiva, 2008.

MILARÉ, Édis. Direito do Ambiente: A gestão ambiental em foco: doutrina, jurisprudência, glossário.6. ed. Ver, atual e ampl. RT, São Paulo, 2009.

OLIVEIRA, B. L. Proporcionalidade no direito ambiental. In LIVIANU, R., (Coord.). Justiça, cidadania e democracia. Rio de Janeiro: Centro Edelstein de Pesquisa Social, 2009. pp. 61-73.

OTERO, Paulo. Legalidade e Administração pública: o sentido da vinculação administrativa à juridicidade. Coimbra: Alamedina, 2003.

SARLET, Ingo Wolfgang; FENSTERSEIFER, Tiago. Direito ambiental: introdução, fundamentos e teoria geral. São Paulo: Saraiva, 2014.

SCHIER, Paulo Ricardo. Ensaio sobre a Supremacia do Interesse Público sobre o Privado e o Regime Jurídico dos Direitos Fundamentais. IN: SARMENTO, Daniel (Org.). Interesses públicos versus interesses privados: descontruindo o princípio de supremacia do interesse público. Rio de Janeiro: Lumen Juris, 2007.

SIRVINSKAS, Luís Paulo. Manual de direito ambiental. 13. ed. São Paulo: Saraiva, 2013.

TAVOLARO, Sérgio Barreira de Faria. Movimento ambientalista e modernidade: Sociabilidade, risco e moral. São Paulo: Annablume/Fapesp, 2001.

Recebido em: 25/05/2018

Aprovado em: 18/07/2018 